\title{
Investigation of Healthy Life and Physical Activity Levels of Prospective Teachers
}

\section{Research Article}

\author{
Ramazan ERDOGAN ${ }^{1}$, Eyup BOZKURT ${ }^{2}$, Mikail TEL ${ }^{3}$ \\ ${ }^{1}$ Bitlis Eren University School of Physical Education and Sport, Bitlis, Turkey., ORCID: 0000-0001-5337-942X \\ 2 Firat University, Department of Basic Education, Elazig, Turkey, ORCID: 0000-0001-8009-3478 \\ ${ }^{3}$ Firat University Faculty of Sport Sciences, Elazig, Turkey, ORCID: 0000-0002-0629-7357
}

To cite this article: Erdogan, R., \& Bozkurt, E., \& Tel, M. (2021). Investigation of healthy life and physical activity levels of prospective teachers, International Online Journal of Educational Sciences, 13(1), 194-204.

\begin{tabular}{ll} 
ARTICLE INFO & ABSTRACT \\
\hline Article History: & $\begin{array}{l}\text { Teachers are role models for students in terms of their life styles and habits. Students make a habit } \\
\text { in their lives by imitating everything teachers do or do not do. In today's world, a healthy lifestyle } \\
\text { and the habit of regular physical activity are important factors that can serve as role models for } \\
\text { seceived: 03.02.2020 }\end{array}$ \\
students. A healthy lifestyle and regular physical activity both increase the quality of life of the \\
teacher and lead the future generations to live a healthy life and to do physical activity regularly. In \\
this study, it was aimed to investigate the healthy lifestyles and physical activity levels of prospective \\
teachers. For this purpose, 25 items were determined using the "Health Life Styles Scale" and applied \\
to prospective teachers. In the conclusion of the study, it was determined that prospective teachers \\
sometimes preferred a regular exercise program and a low-cholesterol diet. Female prospective \\
teachers, compared to male prospective teachers, expressed that they exercised more regularly and \\
were open to new experiences. Majority of them stated that they did not have breakfast regularly. \\
The prospective teachers stated that they sometimes consumed vegetables, sweets and desserts at \\
meals, and they preferred to consume milk, yoghurt and cheese 3-5 times a day. They also stated that \\
they preferred to consume 3-4 portions of foods such as meat, chicken, fish, dried legumes and eggs \\
every day. As a result; it was observed that the healthy lifestyle and physical activity levels of \\
prospective teachers were low.
\end{tabular}

Keywords:

Teacher, Healthy Lifestyle, Physical Activity

(C) 2021 IOJES. All rights reserved

\section{Introduction}

University life is a process in which individuals' lives change significantly. During the university education, it also causes changes in personal development, individual life and health habits as well as

${ }^{1}$ Corresponding author's address: Bitlis Eren University School of Physical Education and Sport

Telephone: +9 05362902979

e-mail:ramaznerdogan@hotmail.com

DOI: https://doi.org/10.15345/iojes.2021.01.013 
vocational training. These changes in the lives of individuals are extremely important, especially in terms of their habits related to healthy living. Because the healthy lifestyles habits newly acquired during the university period determine the health level of the society by affecting the individual himself, his family and the society. (Ilhan et al., 2010).

Healthy lifestyle refers to people's entire movement and behavior to stay healthy, to avoid diseases and to maintain their physical fitness (Soysal and Karaman, 2015). According to the World Health Organization; health is not only the absence of illness or disability, but also a state of complete physical, mental and social well-being (Kostak et al., 2014). In other words, healthy living is aimed not only at preventing disease but also at improving the overall health and physical fitness of individuals. In this sense, today's perception includes understanding health-focused care that protects and enhances individual, family and community health (Kafkas et al., 2012). Today, the concept of health, which examines the physical, physiological and social status of individuals in all aspects, covers the quality of life and the level of satisfaction of individuals in this respect and has become an increasingly important issue. In this context, increasing the number of healthy individuals and minimizing adverse health conditions plays an important role in the overall objectives and plans of the World Health Organization and States (Cihangiroğlu and Deveci, 2011; Med, 2019). Because of work-life stress and workload, as well as limited nutritional habits and physical activity opportunities, teachers' energy expenditure levels in social life are very low, negatively affecting the sustainability of a healthy life. (Arslan and Ceviz, 2007) In this context, nutrition and physical activity are of great importance for the protection and development of a healthy lifestyle.

Nutrition is the consumption of nutrients that individuals need to maintain their vital activities and protect existing health (Yoncalik et al., 2017). Healthy nutrition is the use of all the nutrients that people need by taking into account their physical characteristics. Nutritional requirements vary according to the age, sex, disease and physical activity status of individuals. (Altay et al., 2018; Saygin et al., 2011; Arslan, 2018; Ermis et al., 2015). Inadequate and unbalanced nutrition that occurs as a result of changes in nutritional habits along with changing living conditions, causes serious health problems (obesity, cardiovascular diseases, etc.) (Gurbuz and Yetis, 2018). In order to prevent such adversities in the organism, nutritional and physical activity habits must be acquired at an early age, as many habits acquired. (Murphey et al., 2011).

Physical activity is expressed as physical movements (walking, running, eating, etc.) that individuals spend certain amounts of energy in everyday life. Physical activity is as important as adequate and balanced nutrition for maintaining a healthy life (Arslan et al., 2018). Physical activities from an early age create positive changes in the organism. As a result of physical activities, positive effects such as aerobic capacity, body composition, skeletal-muscle health, prevention of obesity, prevention of diabetes and preservation of physical fitness occur in the organism.(Lee et al., 2012; Danaei et al., 2009). In this context, this study was conducted to determine the healthy lifestyles and physical activity levels of prospective teachers.

\section{Objective of the Study}

In this study, it was aimed to examine the healthy lifestyle and physical activity levels of prospective teachers. For this purpose, healthy lifestyles and physical activity levels were examined and evaluated by taking the opinions of prospective teachers. The following sub-goals were sought for the achievement of the purpose.

- What are the opinions of the preservice teachers participating in the study on healthy lifestyles?

- Is there a difference between the healthy lifestyle and physical activity levels of the prospective teachers participating in the study according to the gender variable? 


\section{Material and Method}

\section{Study Model}

This study, which aims to determine the nutritional habits and physical activity levels of prospective teachers, is a type of scanning model and has a descriptive quality. Studies aimed at collecting data to determine specific characteristics of a group are called scanning research (Buyukozturk et al., 2009).

\section{Population and Sample}

The population of the study constitute 1500 prospective teachers studying at the Faculty of Education at Frrat University in 2018-2019 academic year. The sample of the study consists of 401 prospective teachers studying at Firat University, Faculty of Education, and the participants were selected by random method.

\section{Data Analysis}

"The Healthy Life Behaviors Scale", the reliability and validity of which was made by Bahar et al., (2008), was used to collect the data. This scale, consisting of 52 items, was reduced to 25 items by taking the opinions of a total of four experts, two in the field of classroom education and two in the field of physical education, and applied by finalizing the scale. The SPSS statistical package program was utilized for data analysis. As a result of the analysis, KMO value of the scale which was reduced to 25 items was found as .720 and Cronbach alpha value was found as .898 . This result shows that the scale was valid and reliable. The data obtained from the research were analyzed using "Arithmetic mean," "percentage" and frequency. Additionally, the degree to which teacher opinions were influenced by variables based on demographic data was also performed by independent $t$ test groups. The arithmetic mean value ranges of the scale consisting of four-point Likert were evaluated as follows:

\section{1,00-1,75: Never}

1,76-2,51: Sometimes

2,52-3,27: Frequently

3,28-4,00: Regularly

\section{Findings}

In this section, the demographic information of the prospective teachers participating in the study and the findings obtained regarding the determination of healthy lifestyles were showed in tables.

Findings Regarding the Demographic and Healthy Life Styles of Prospective Teachers

Table 1. Personal Information Related to the Research Group

\begin{tabular}{llll}
\hline \multirow{2}{*}{ Gender } & & Frequency & Percentage (\%) \\
\hline \multirow{4}{*}{ Height $(\mathrm{cm})$} & Female & 217 & 54,1 \\
\cline { 2 - 4 } & Male & 184 & 45,9 \\
\cline { 2 - 4 } & $150-160$ & 69 & 17,2 \\
\cline { 2 - 4 } & $161-170$ & 125 & 31,2 \\
\cline { 2 - 4 } Age & $171-180$ & 148 & 36,9 \\
\cline { 2 - 4 } & 181 -and longer & 59 & 14,7 \\
\hline \multirow{3}{*}{ Weight $(\mathrm{kg})$} & $18-20$ & 181 & 45,2 \\
\cline { 2 - 4 } & $21-23$ & 146 & 36,5 \\
\cline { 2 - 4 } & 24 and older & 73 & 18,2 \\
\cline { 2 - 4 } & $45-55$ & 144 & 35,9 \\
\cline { 2 - 4 } & $56-65$ & 57 & 139,2 \\
\hline
\end{tabular}


The examination of Table 1 showed that $54.1 \%$ of the prospective teachers who took part in the study were female, and $45.9 \%$ were male; $17.2 \%$ were $150-160 \mathrm{~cm}, 31.2 \%$ were $161-170 \mathrm{~cm}, \% 36.9$ were $171-180 \mathrm{~cm}$ and $14.7 \%$ were $181 \mathrm{~cm}$ and above; $36.5 \%$ were 18 -20-year-old $18.2 \%$ were 21 -23-year-old and $18.2 \%$ were 24 years old and over. $15.2 \%$ of them were $45-55 \mathrm{~kg}, 35.9 \%$ were $56-65 \mathrm{~kg}, 34.7 \%$ were $66-75 \mathrm{~kg}$ and $14.2 \%$ were $76 \mathrm{~kg}$ and above.

Table 2. Distribution of Prospective Teachers' General Views on Healthy Lifestyles

\begin{tabular}{|c|c|c|c|c|c|c|c|c|}
\hline \multirow[t]{2}{*}{ Item } & \multirow[t]{2}{*}{ Healthy Lifestyles } & \multicolumn{7}{|c|}{ Degree Of Participation (\%) } \\
\hline & & $\mathbf{n}$ & $\stackrel{\bar{d}}{\grave{z}}$ & 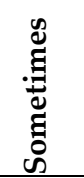 & 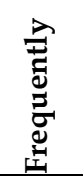 & 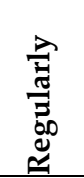 & $\bar{X}$ & sd \\
\hline 1 & I follow a regular exercise program. & 401 & 45,6 & 34,4 & 14,5 & 5,5 & 1,79 & 0,88 \\
\hline 2 & $\begin{array}{l}\text { I prefer a diet low in liquid and solid fat, and } \\
\text { cholesterol. }\end{array}$ & 401 & 23,9 & 59,1 & 11,7 & 5,2 & 1,98 & 0,75 \\
\hline 3 & I get enough sleep. & 399 & 22,8 & 35,6 & 24,3 & 17,3 & 2,36 & 1,01 \\
\hline 4 & I cut down sugar and dessert & 401 & 35,2 & 34,7 & 20,9 & 9,2 & 2,04 & 0,96 \\
\hline 5 & $\begin{array}{l}\text { I exercise for } 20 \text { minutes and/or longer at least three } \\
\text { times a week. }\end{array}$ & 395 & 24,8 & 45,6 & 20,8 & 8,9 & 2,13 & 0,89 \\
\hline 6 & $\begin{array}{l}\text { I eat 6-11 meals of bread, cereal, rice and pasta every } \\
\text { day. }\end{array}$ & 401 & 34,9 & 42,6 & 18,5 & 4,0 & 1,91 & 0,82 \\
\hline 7 & $\begin{array}{l}\text { I do light and moderate exercise (for example, I walk } 5 \\
\text { times a week or more). }\end{array}$ & 401 & 17,7 & 34,7 & 33,2 & 14,5 & 2,44 & 0,94 \\
\hline 8 & I eat 2-4 portions of fruit every day. & 401 & 12,5 & 48,9 & 29,7 & 9,0 & 2,35 & 0,81 \\
\hline 9 & $\begin{array}{l}\text { In my spare time, I do entertaining physical activities } \\
\text { such as swimming, dancing, cycling. }\end{array}$ & 401 & 30,7 & 42,4 & 21,9 & 5,0 & 2,01 & 0,85 \\
\hline 10 & I eat 3-5 portions of vegetables every day. & 401 & 6,5 & 54,4 & 27,2 & 12,0 & 2,44 & 0,78 \\
\hline 11 & $\begin{array}{l}\text { I consult medical professionals about my health } \\
\text { problems. }\end{array}$ & 392 & 31,9 & 29,8 & 26,3 & 12,0 & 2,18 & 1,01 \\
\hline 12 & I use appropriate methods to control my stress. & 401 & 21,9 & 49,4 & 19,0 & 9,7 & 2,16 & 0,87 \\
\hline 13 & I eat milk, yoghurt or cheese 3-5 times every day. & 400 & 31,0 & 33,0 & 25,5 & 10,5 & 2,15 & 0,98 \\
\hline 14 & $\begin{array}{l}\text { I check my body at least once a month for physical } \\
\text { changes, dangerous signs. }\end{array}$ & 401 & 22,7 & 46,9 & 23,7 & 6,7 & 2,14 & 0,84 \\
\hline 15 & I exercise during the day's work. & 401 & 43,1 & 28,2 & 18,2 & 10,5 & 1,96 & 1,01 \\
\hline 16 & $\begin{array}{l}\text { I eat 3-4 portions of meat, chicken, fish, pulses, eggs, } \\
\text { snacks every day. }\end{array}$ & 401 & 29,7 & 41,1 & 15,7 & 13,5 & 2,12 & 0,98 \\
\hline 17 & When I exercise, I check my pulse and heart rate. & 401 & 38,2 & 35,9 & 16,7 & 9,2 & 1,97 & 0,95 \\
\hline 18 & I practice to relax and relax for 15-20 minutes a day. & 401 & 23,4 & 40,4 & 22,7 & 13,5 & 2,26 & 0,96 \\
\hline 19 & $\begin{array}{l}\text { I read labels on food packages that identify the } \\
\text { nutrients, fats and sodium content. }\end{array}$ & 394 & 25,1 & 31,5 & 23,1 & 20,3 & 2,38 & 1,07 \\
\hline 20 & $\begin{array}{l}\text { I participate in training programs related to individual } \\
\text { health care. }\end{array}$ & 401 & 22,2 & 46,1 & 19,7 & 12,0 & 2,21 & 0,92 \\
\hline 21 & I have breakfast. & 397 & 15,4 & 42,3 & 24,4 & 17,9 & 2,44 & 0,95 \\
\hline 22 & I protect myself from exhaustion. & 384 & 19,0 & 47,1 & 23,2 & 10,7 & 2,25 & 0,88 \\
\hline 23 & $\begin{array}{l}\text { I do muscle building exercises at least three times a } \\
\text { week. }\end{array}$ & 401 & 32,4 & 35,9 & 18,7 & 13,0 & 2,12 & 1,00 \\
\hline 24 & I'm open to new experiences and situations. & 401 & 17,0 & 29,5 & 24,2 & 29,2 & 2,65 & 1,07 \\
\hline 25 & I feel at peace with myself and I feel adequate. & 401 & 10,2 & 22,4 & 23,4 & 43,9 & 3,01 & 1,03 \\
\hline
\end{tabular}


The examination of Table 2 showed that prospective teachers who participated in the study stated their opinions on the level of "sometimes" "I follow a regular exercise program" $(X=1,79)$ and "I prefer a diet low in liquid and solid fat, cholesterol" $(X=1,98)$ opinion clauses.

The examination of Table 2 also showed that prospective teachers stated their opinions on the level of "sometimes" for the opinion clauses; I get enough sleep" ( $X=2,36)$, "I cut down sugar and dessert" $(X=2,04)$, "I exercise for 20 minutes and/or longer at least three times a week" $(X=2,13)$, "I eat 6-11 meals of bread, cereal, rice and pasta every day" $(X=1,91)$, "In my spare time, I do entertaining physical activities such as swimming, dancing, cycling" $(X=2,01)$, "I eat 3-5 meals of vegetables every day" $(X=2,44)$, "I consult with the medical professionals about my health problems" $(X=2,18)$, "I use appropriate methods to control my stress" $(X=2,16)$.

The examination of Table 2 revealed that prospective teachers stated their opinions on the level of "sometimes" for the opinion clauses; "I eat milk, yoghurt or cheese 3-5 times every day" ( $X=2,15)$, "I check my body at least once a month for physical changes, dangerous signs" $(X=2,14)$, "I exercise during the daily work" $(X=1,96)$, "I eat 3-4 portions of meat, chicken, fish, pulses, eggs, snacks every day" $(X=2,12)$, "I check my pulse and heart rate when I exercise" $(X=1,97)$, "I practice to relax for 15-20 minutes a day" $(X=2,26)$, "I read labels on food packages that identify the nutrients, fats and sodium content" $(X=2,38)$.

The examination of Table 2 also showed that prospective teachers stated their opinions on the level of "sometimes" for the opinion clauses; "I have breakfast" ( $X=2,4)$, "I protect myself from exhaustion" $(X=2,25)$, "I do muscle building exercises at least three times a week" ( $X=2,12)$; and "Frequently" for the opinion clauses; "I'm open to new experiences and situations" $(X=2,65)$, "I feel at peace with myself and I feel adequate" $(X=3,01)$.

\section{T Test Results of Prospective Teachers Participating in the Study According to the Gender Variable}

Table 3. Prospective Teachers' views on healthy lifestyles according to gender variable

\begin{tabular}{|c|c|c|c|c|c|c|}
\hline Healthy Lifestyles & Gender & n & $\overline{\mathrm{X}}$ & Sd & $\mathbf{t}$ & $\mathbf{p}$ \\
\hline \multirow{2}{*}{ I follow a regular exercise program. } & Male & 217 & 1,59 & 0,86 & \multirow{2}{*}{2,001} & \multirow{2}{*}{$0,028^{*}$} \\
\hline & Female & 184 & 2,03 & 0,84 & & \\
\hline \multirow{2}{*}{ I cut down sugar and dessert } & Male & 217 & 1,78 & 0,90 & \multirow{2}{*}{2,147} & \multirow{2}{*}{$0,016^{*}$} \\
\hline & Female & 184 & 2,34 & 0,94 & & \\
\hline \multirow{2}{*}{$\begin{array}{l}\text { I do light and moderate exercise (for } \\
\text { example, I walk } 5 \text { times a week or } \\
\text { more). }\end{array}$} & Male & 217 & 2,35 & 1,00 & \multirow[b]{2}{*}{2,202} & \multirow[b]{2}{*}{$0,006^{*}$} \\
\hline & Female & 184 & 2,55 & 0,85 & & \\
\hline \multirow{2}{*}{$\begin{array}{l}\text { I read labels on food packages that } \\
\text { identify the nutrients, fats and } \\
\text { sodium content. }\end{array}$} & Male & 217 & 2,24 & 1,16 & \multirow[b]{2}{*}{2,334} & \multirow[b]{2}{*}{$0,005^{*}$} \\
\hline & Female & 184 & 2,54 & 0,93 & & \\
\hline \multirow{2}{*}{ I have breakfast. } & Male & 217 & 2,30 & 0,94 & \multirow{2}{*}{2,418} & \multirow{2}{*}{$0,003^{*}$} \\
\hline & Female & 184 & 2,60 & 0,95 & & \\
\hline \multirow{2}{*}{$\begin{array}{l}\text { I'm open to new experiences and } \\
\text { situations. }\end{array}$} & Male & 217 & 2,47 & 1,11 & \multirow{2}{*}{2,431} & \multirow{2}{*}{$0,03^{*}$} \\
\hline & Female & 184 & 2,87 & 0,98 & & \\
\hline
\end{tabular}

The examination of Table 3 showed that according to the gender variable of prospective teachers who participated in the study, there was a significant difference in items 1, 4, 7, 19, 21 and 24 at the level of $\mathrm{p}<.05$. There was no significant difference compared to the gender variable in other clauses.

According to table 3 it was seen that there was a significant difference as a result of the analysis made according to the gender variable of the prospective teachers participating in the study in the item 1, "I follow a regular exercise program" $[t=-2,001 ; p<.05]$. This opinion item was accepted by female teachers more than male teachers $(X=1,59)$. 
The examination of Table 3 showed that there was a significant difference in the gender variable of the prospective teachers who participated in the study according to the opinion clause "I cut down sugar and sweet" which was the 4 th clause $[\mathrm{t}=-2,147 ; \mathrm{p}<.05]$. This opinion clause was more accepted by female teachers $(X=2,34)$ than male teachers $(X=1,78)$.

According to table 3 it was observed that there was a significant difference in the analysis according to the gender variable of the prospective teachers who participated in the opinion item 7 "I do light and moderate exercise (for example, I walk 5 times a week or more). [t=-2,202; $\mathrm{p}<.05]$. This opinion clause was more accepted by female teachers $(X=2,55)$ than male teachers $(X=2,35)$.

The examination of Table 3 showed that there was a significant difference in the analysis according to the gender variable of the prospective teachers who participated in the opinion clause "I read labels on food packages that identify the nutrients, fats and sodium content.", which was the 19th clause. [t=-2,334; $\mathrm{p}<.05]$. This opinion clause was more accepted by female teachers $(X=2,54)$ than male teachers $(X=2,24)$.

The examination of Table 3 also showed that there was a significant difference in the analysis according to the gender variable of the prospective teachers who participated in the opinion clause "I have breakfast", which was the 21st clause. [t=-2,418; $\mathrm{p}<.05]$ This opinion clause was more accepted by female teachers $(X=2,60)$ than male teachers $(X=2,30)$.

The examination of Table 3 revealed that there was a significant difference in the gender of the prospective teachers who participated in the opinion clause "I am open to new experiences and situations", which was clause 24 . $[t=-2,431 ; p<.05]$ This opinion clause was more accepted by female teachers $(X=2,87)$ than male teachers $(X=2,47)$.

\section{Discussion and Conclusions}

The study revealed that $45.6 \%$ of the prospective teachers never participated in a regular exercise program, while $34.4 \%$ sometimes participated in a regular exercise program. $23.9 \%$ of the participants stated that they never preferred a diet low in cholesterol, while $59.1 \%$ stated that they sometimes preferred a diet low in cholesterol. Monteiro et al. (2019) examined the physical activity, weight status and eating habits of young adults in Brazil and according to their study, nearly half of the participants stated that they did less than 150 minutes of physical activity per week and women had more sedentary lifestyles than men. In their study, Giontella, et al. (2019) stated that the participants had a low level of physical activity and therefore a high level of obesity. Akbulut et al. (2016) examined the nutritional and health status of university students and determined that participants had incorrect nutritional habits and their physical activity levels were inadequate. Toktaş et al. (2018) stated that the levels of physical activity and nutrition were low in their study which investigated the Healthy Living physical activity levels of university students. Bozkurt and Erdoğan (2019) determined that the physical activity levels of the participants were inadequate in their study that they examined the eating habits of classroom teachers. Salameh et al. (2014) found in their study about university students that nearly one fourth $(26.8 \%)$ chose low-calorie diets. Our research results showed similarities with the literature. It may be due to the lack of a regular physical activity program, irregular lifestyle and nutritional habits of the prospective teachers, as well as limited areas of sports and social activities at the university.

The prospective teachers participating in the study stated that they sometimes fulfilled the occasions referred in opinion items such as sleeping, cutting down sugar and sweets, consuming vegetables frequently at meals, exercising adequately. In addition, female prospective teachers stated that they were more likely to accept opinion items "I eat breakfast, I cut down sugar and sweets, I read the labels determining the nutrient, fat and sodium contents on food packages" more than male prospective teachers. In the study, Onurlubas et al. (2015) examined the nutritional habits of university students and found that females skipped more meals than males. Ayhan et al. (2012), in a study examining the nutritional habits of medical faculty students, stated 
that red meat was consumed most, and although the consumption of bread and pastry was high, the consumption of vegetables and fruits was less. The prospective teachers' irregular eating habits and their inability to participate in exercise programs may be due to the intensity of university life. In addition, the sensitivity of female students to nutrition compared to male students may be related to the fact that female students care more about their health and physical appearance than male students.

The prospective teachers participating in the study stated that they sometimes do activities such as swimming and dancing in their spare time and they sometimes consult health personnel for health problems. Sabbağ and Aksoy (2011) examined the leisure time of university students and academic staff and found that the majority of the people watched TV, VCD, DVD, read books, did sports, friends / chat / travel, internet and music activities every day, and they stated they went cinema, theater, concert or attended university events once a week or a month. Tel and Erdoğan (2015) examined the leisure time activities of physicians and stated that the majority of them watched television, DVD, VCD, etc., read books, newspapers and magazines, listened to music and played musical instruments. Yagmur and Ocak (2012) stated that the vast majority of university students participated in sports, music and gaming activities during their free time. Prospective teachers' insufficient participation in social activities may be related to the intensity of educational activities, environmental factors and cultural differences.

The prospective teachers participating in the study stated that they consumed milk, yogurt and cheese 3-5 times a day, ate 3-4 portions of foods such as meat, chicken, fish, dried legumes, eggs every day, and sometimes read the labels on food packages related to the content of food, fat and sodium. Onurlubaş et al. (2015) stated that the students who participated in the study always consumed the most cereal products, excessive eggs, vegetables and fruits at least once a week. Onurlubaş et al. (2015) in their study in which they investigated the nutritional habits of university students, stated that students consumed most cereal products every day, eggs every other day, vegetables and fruits at least once a week. Erçim and Pekcan (2014) examined the nutritional status of young adults and stated that women's consumption of fruits and vegetables was higher than men's and determined that sodium intake, fat and grain consumption of men were higher than women. Bayır and Güçlü (2018) stated in their study in which students nutritional habits were determined, that the most skipped meal was breakfast, and they regularly consumed eggs, milk and dairy products. Kalkan et al. (2018) stated in their study in which university students' nutritional and physical activity levels were examined, the majority of them consumed milk and dairy products, vegetables and fruits every day; and dried legumes and fish at least once a week. The lack of regular eating habits of the prospective teachers may be related to the fact that the participants do not have enough knowledge about nutrition.

The prospective teachers participating in the study stated that they sometimes participated in training programs related to having breakfast, protecting themselves from getting tired, doing exercises to strengthen muscles, and individual health care. Al-Hazzaa and Albawardi (2019) in their study which they examined the eating habits of Saudi youth, stated that a great majority of them did not have breakfast regularly. Yilmaz and Özkan (2007), in their study examining the eating habits of university students, stated that most of them skipped meals and that the most skipped meals were lunch, breakfast and dinner, respectively. Ermiş, et al. (2014) stated that most of the university students participating in the study did not exercise regularly and the most skipped meal was breakfast. In the study Cinar et al. (2016) examined the healthy lifestyle behaviors of coaches working in the Turkish Wrestling Federation, they found that the majority of them occasionally exercised and the frequency of physical activity of coaches varied according to age, seniority and working year. In their study Tanriverdi et al. (2011) examined the nutritional attitudes of high school students and found that the most skipped meal was breakfast and most of the students expressed that they consumed fast food most. Arslan, et al. (2003) in their study examining the relationship between the physical activity levels and health problems of faculty members, stated that the participation rate of the majority of the faculty 
members in physical activity remained low. The fact that prospective teachers do not have a regular and balanced nutrition program may be due to the irregular living conditions brought by university life.

The female prospective teachers participating in the study stated that they did regular, light and moderate exercises and accepted that they were more open to new experiences than male peospective teachers. In their study on women, Karabulut and Altun (2018) stated that 55.9\% did not do exercise regularly. In their study, Özveren and Yilmaz (2018) determined that male students had higher physical activity status score averages than female students. İskender, et al. (2018) stated that the majority of university students did not have the habit of exercise in their study examining the healthy life and depression levels of university students. The fact that female students exercise regularly compared to male students may be related to the fact that women care more about their physical and aesthetic appearance than male students.

As a result, it was understood that prospective teachers did not have a regular nutritional habit, they generally skipped meals and preferred fast foods, did not participate in a regular exercise program and social activities sufficiently. In addition, it was observed that female students exercised regularly and gave more importance to nutrition and healthy living than male students.

\section{Suggestions}

- Informative trainings about healthy nutritional habits should be given to by organizing seminars and panels by public institutions and universities.

- Informative studies that will explain the importance of physical activity should be carried out by experts and trainers, and ways of doing physical activity should be taught.

- Studies can be carried out for prospective teachers to fully learn and apply the effects of healthy nutrition on our lives.

- Researchers can conduct studies to determine healthy eating patterns of teachers.

- Researchers can make studies that determine the healthy diet of teachers.

- Researchers can conduct studies to measure the knowledge levels of about healthy living.

- Researchers can make studies to measure the knowledge level of teacher candidates in terms of healthy living.

- Researchers can conduct studies to investigate how much information teachers could provide to their students about healthy living. 


\section{REFERENCES}

Akbulut, T., Çınar, V., Erdoğan, R., \& Murathan, F. (2016). Evaluation of Nutrition and Health Condition Levels in Students Who Studying At Faculty of Sport Sciences (Sample of Firat University, Elazig). Annals of" Dunarea de Jos" University of Galati-Fascicle XV: Physical Education and Sport Management, (2).

Al-Hazzaa H. M., \& Albawardi, N. M. (2019). Activity Energy Expenditure, Screen Time and Dietary Habits Relative to Gender among Saudi Youth: Interactions of Gender with Obesity Status and Selected Lifestyle Behaviours.Asia Pacific Journal of Clinical Nutrition, 28(2), 389-400.

Altay, M., Cabar, H. D., \& Altay, B. (2018). Adolesan Dönemi Çocuklarda Beslenme ve Okul Sağlı̆̆ı. Sinop Üniversitesi Sosyal Bilimler Dergisi, 2(3), 173-180.

Arslan, C., \& Ceviz, D. (2007). Ev Hanımı ve Çalışan Kadınların Obezite Prevalansı Ve Sağlıklı Yaşam Biçimi Davranışlarının Değerlendirilmesi. Fırat Üniversitesi Sağlık Bilimleri Dergisi, 21(5), 211-220.

Arslan, C., Koz, M., Gür, E., \& Mendeş, B. (2003).Üniversite Öğretim Üyelerinin Fiziksel Aktivite Düzeyleri Ve Sağlık Sorunları Arasındaki İlişkinin Araştırılması. Fırat Üniversitesi Sağlık Bil. Dergisi, 17(4), $249-258$.

Arslan, M. (2018). Beslenme Alışkanlıkları ve Fiziksel Aktivite Düzeylerinin Analizi: Marmara Üniversitesi Öğretim Üyeleri Üzerine Bir Çalışma. Dicle Tıp Dergisi, 45(1), 59-69.

Arslan, S. S., Alemdaroğlu, İ., Öksüz, Ç., Karaduman, A. A., \& Yılmaz, Ö. T. (2018). Genç Bireylerde Fiziksel Aktivitenin Akademik Başarı ve Depresyon Üzerine Etkisi. Ergoterapi ve Rehabilitasyon Dergisi, 6(1), 3742.

Ayhan, D. E., Günaydın, E., Gönlüaçık, E., Arslan, U., Çetinkaya, F., Asımı, H., \& Yeşim, U. N. C. U. (2012). Uludağ Üniversitesi Tıp Fakültesi Öğrencilerinin Beslenme Alışkanlıkları ve Bunları Etkileyen Faktörler. Uludă̆ Üniversitesi Tıp Fakültesi Dergisi, 38(2), 97-104.

Bahar, Z., Beşer, A., Gördes, N., Ersin, F., \& Kıssal, A. (2008). Sağlıklı Yaşam Biçimi Davranışları Ölçeği II'nin Geçerlilik Ve Güvenirlilik Çalışması. Cumhuriyet Üniversitesi. Hemşirelik Yüksekokulu Dergisi, 12(1), 113.

Bayır, A. G., \& Güçlü, D. (2019). Nutritional Assessment and Physical Activity of the Departments For Nutrition\&Dietetics and Nursing Students at A Foundation University. Bezmialem Science, 7(2), 132-137.

Bozkurt, E., \& Erdoğan, R. (2019). Sınıf Öğretmenlerinin Beslenme Alışkanlıklarının İncelenmesi. Uluslararası Toplum Araştırmaları Dergisi, 9(13), 75-94.

Büyükzötürk Ş., Çakmak. E. K.. Akgün. Ö. E.. Karadeniz. Ş. \& Demirel. F. (2009). Bilimsel Araştırma Yöntemleri. [Scientific Research Methods]. Ankara: Pegem

Cihangiroğlu, Z., \& Deveci, S. E. (2011). Fırat Üniversitesi Elazığ Sağlık Yüksekokulu Öğrencilerinin Sağlıklı Yaşam Biçimi Davranışları ve Etkileyen Faktörler. Fırat Tıp Dergisi, 16(2), 78-83.

Çinar, V., Akbulut, T., Öner, S., Pancar, Z., \& Karaman, M. E. (2016). Türkiye Güreş Federasyonu'ndaki Antrenörlerin Sağlıklı Yaşam Biçimi Davranışlarının İncelenmesi. Uluslararası Hakemli Akademik Spor Sağlık ve Tıp Bilimleri Dergisi, 21,119-136.

Danaei, G., Ding, E. L., Mozaffarian, D., Taylor, B., Rehm, J., Murray, C. J., \& Ezzati, M. (2009). The Preventable Causes of Death in the United States: Comparative Risk Assessment of Dietary, Lifestyle, and Metabolic Risk Factors. Plos Medicine, 6(4),1-23. 
Erçim, R. E., \& Pekcan, G. (2014). Genç Yetişkinlerin Beslenme Durumunun Sağlıklı Yeme İndeksi-2005 İle Değerlendirilmesi. Beslenme ve Diyet Dergisi, 42(2), 91-98.

Ermiş, E., Doğan, E., Erilli, N., \& Satıcı, A. (2015). Üniversite Öğrencilerinin Beslenme Alışkanlıklarının İncelenmesi: Ondokuz Mayıs Üniversitesi Örneği. Spor ve Performans Araştırmaları Dergisi, 6(1), 30-40.

Giontella, A., Bonafini, S., Tagetti, A., Bresadola, I., Minuz, P., Gaudino, R., ... \& Fava, C. (2019). Relation between Dietary Habits, Physical Activity, and Anthropometric and Vascular Parameters in Children Attending the Primary School in the Verona South District. Nutrients, 11(5).

Gürbüz, P., \& Yetiş, G. (2018). Sağlık Hizmetleri Meslek Yüksekokulu Öğrencilerinin Beslenme Alışkanlıklarının Belirlenmesi. İnönü Üniversitesi Sağlık Hizmetleri Meslek Yüksek Okulu Dergisi, 6(2), 5463.

İlaslan, E., Taylan, S., Özkan, İ., \& Adıbelli, D. (2020). Bir İlçedeki Üniversite Öğrencilerinin Fiziksel Aktivite Düzeyleri ve İlişkili Faktörlerin İncelenmesi. Türkiye Klinikleri İç Hastalıkları Dergisi, 5(1), 15-21.

İlhan, N., Batmaz, M., \& Akhan, L. U. (2010). Üniversite Öğrencilerinin Sağlıklı Yaşam Biçimi Davranışları. Maltepe Üniversitesi Hemşirelik Bilim ve Sanatı Dergisi, 3(3), 34-44.

İskender, H., Dokumacıŏ̆lu, E., Kanbay, Y., \& Kılıç, N. (2018). Üniversite Öğrencilerinde Sağlıklı Yaşam ve Depresyon Puan Düzeyleri ile İlgili Faktörlerin Belirlenmesi. Acıbadem Üniversitesi Sağlık Bilimleri Dergisi, 9(4), 414-423.

Kafkas, M. E., Kafkas, Ş. A., \& Acet, M. (2012). Beden Eğitimi Ö̆ğretmenlerinin Sağlıklı Yaşam Biçimi Davranış Düzeylerinin İncelenmesi. Dumlupinar Üniversitesi Sosyal Bilimler Dergisi, 32(2), 47-56.

Kalkan, İ., Pehlivan, M., Öztürk, S. A., \& Ersoy, G. (2018). İstanbul Aydın Üniversitesi Beslenme ve Diyetetik 1. Sınıf Öğrencilerinin Beslenme Alışkanlıkları ve Fiziksel Aktivite Düzeylerinin Saptanması. Aydın Sağlık Dergisi, 4(1), 45-60.

Karabulut, E. O. \& Altun, M. (2018). Düzenli Olarak Spor Yapan ve Yapmayan Kadınların Sağlıklı Yaşam Biçimi Davranışlarının Farklı Değişkenler Bakımından İncelenmesi: Kırşehir İli Örneği. Ahi Evran Üniversitesi Kırşehir Ĕ̆itim Fakültesi Dergisi, 19(1), 936-948.

Kostak, M. A., Kurt, S., Süt, N., Akarsu, Ö., \& Ergül, G. D. (2014). Hemşirelik ve Sınıf Öğretmenliğgi Öğrencilerinin Sağlıklı Yaşam Biçimi Davranışları. TAF Preventive Medicine Bulletin, 13(3), 189-196.

Lee, I. M., Shiroma, E. J., Lobelo, F., Puska, P., Blair, S. N., Katzmarzyk, P. T., \& Lancet Physical Activity Series Working Group.. (2012). Effect of Physical Inactivity on Major Non-Communicable Diseases Worldwide: An Analysis of Burden of Disease and Life Expectancy. Lancet, 380(9838), 219-229.

Med, A. J. F. (2019). Healthy Living Behaviors in University Students and Related Factors. The Anatolian Journal of Family Medicine, 2(1), 2-6.

Monteiro, L. Z., Varela, A. R., de Lira, B. A., Contiero, L. C., Carneiro, M. D. L. A., de Souza, P., ... \& Júnior, F. B. (2019). Weight Status, Physical Activity and Eating Habits of Young Adults in Midwest Brazil. Public Health Nutrition, 1-8.

Murphey, D.,Mackintosh, B. \& McCoy-Roth, M. (2011). Early Childhood Policy Focus: Healthy Eating and Physical Activity. Child Trends: Early Childhood Highlights, 2(3), 1-9.

Onurlubaş, E., Doğan, H. G., \& Demirkıran, S. (2015). Üniversite Öğrencilerinin Beslenme Alışkanlıkları. Gaziosmanpaşa Üniversitesi Ziraat Fakültesi Dergisi, 32(3), 61-69. 
Özveren, H., \& Yılmaz, E.D. (2018). Hemşirelik Öğrencilerinin Sağlıklı Yaşam Biçimi Davranışları İle Egzersiz Davranışlarının İncelenmesi. Journal of Human Sciences, 15(3), 1505-1518.

Sabbağ, Ç., \& Aksoy, E. (2011). Üniversite Öğrencileri Ve Çalışanların Boş Zaman Etkinlikleri: Adıyaman Örneği. Mehmet Akif Ersoy Üniversitesi Sosyal Bilimler Enstitüsü Dergisi, (4), 10-23.

Salameh, P., Jomaa, L., Issa, C., Farhat, G., Salamé, J., \& Zeidan, N., (2014). Lebanese National Conference for Health in University Research Group. Assessment of Dietary Intake Patterns and Their Correlates among University Students in Lebanon. Frontiers In Public Health, 2, 185.

Saygın, M., Öngel, K., Çalışkan, S., Yağlı, M. A., Has, M., Gonca, T., \& Kurt, Y. (2011). Süleyman Demirel Üniversitesi öğrencilerinin beslenme alışkanlıkları. Süleyman Demirel Üniversitesi Tıp Fakültesi Dergisi, $18(2), 43-47$.

Soysal, A., Karaman, M., \& Alıcı, H. (2015). Meslek Yüksekokulu Öğrencilerinin Sağlıklı Yaşam Biçimi Davranışları ve Bu Davranışları Etkileyen Faktörler. Journal of Current Researches on Health Sector, 8(2), 49-66.

Tanrıverdi, D., Savaş, E., Gönüllüoğlu, N., Kurdal, E., \& Balık, G. (2011). Lise Öğrencilerinin Yeme Tutumları, Yeme Davranışları ve Benlik Saygılarının İncelenmesi. Gaziantep Medical Journal, 17(1), 33-39.

Tel, M., \& Erdoğan, R. (2015). Doktorların Boş Zaman Etkinliğine Katılma Durumlarının İncelenmesi. International Journal of Science Culture and Sport, 3(Special Issue 4), 383-395.

Toktaş, N., Erman, A. K., \& Yetik, O. (2018). Erkek Üniversite Öğrencilerinin Kronotipe Göre Sağlıklı Yaşam Biçimi Davranışları ve Fiziksel Aktivite Düzeyleri. Abant İzzet Baysal Üniversitesi Eğitim Fakültesi Dergisi, 18 (1), 507-520.

Yağmur, R., \& Ocak, Y. (2006). Afyon Kocatepe Üniversitesi Beden Eğitimi ve Spor Yüksekokulu Öğrencileri İle Farklı Bölümlerdeki Öğrencilerin Serbest Zaman Aktivitelerinin Karşılaştırılması. Spor ve Performans Araştırmaları Dergisi, 4(1), 5-16.

Yılmaz, E., \& Özkan, S. (2007). Üniversite Öğrencilerinin Beslenme Alışkanlıklarının İncelenmesi. Fırat Sağllk Hizmetleri Dergisi, 2(6), 87-104.

Yoncalık, M. T., Aslan, E., \& Yaka, M. (2017). Fizik Tedavi ve Rehabilitasyon Alan Hastaların Fiziksel Aktivite Düzeyleri ile Sağlıkı Yaşam Davranışı Biçimleri Arasındaki İlişkinin İncelenmesi. Gaziantep Üniversitesi Spor Bilimleri Dergisi, 2(3), 57-68. 